Резюме

Михневич Л.В. Конституционное право на тайну переписки, телефонных разговоров, телеграфной и другой корреспонденции отдельных категорий лиц.

В статье исследовано право на тайну переписки, телефонных разговоров, телеграфной и другой корреспонденции отдельных категорий лиц, в частности право на тайну корреспонденции лиц, осужденных к лишению свободы, представителей государственной власти, адвокатов. Также охарактеризованы две научные концепции понимания права на тайну корреспонденции. Осуществлен анализ последних нормативных изменений правового регулирования обеспечения права на тайну корреспонденции в Украине, в частности изменения гарантий права на тайну корреспонденции народных депутатов Украины.

Ключевые слова: личностная концепции права на тайну корреспонденции, право на тайну переписки, телефонных разговоров, телеграфной и другой корреспонденции, право на частную жизни, право на семейную жизни, лица, осужденные к лишению свободы, народные депутаты, адвокаты.

\title{
Summary
}

Liudmyla Mikhnevych. The constitutional right to the confidentiality of listening, telephone conversation, telegraph and other correspondence of separate categories of persons.

The right to the confidentiality of listening, telephone conversation, telegraph and other correspondence of separate categories of persons is researched in the article. It is establishes that despite all legal guarantees, the right to the confidentiality of correspondence is provided differently for separate categories of persons. The least secure of this right are those sentenced to imprisonment, and people's deputies, lawyers and other persons in respect of which a special procedure of criminal proceedings is carried out have the highest immunity from illegal or arbitrary interference with the right to confidentiality of correspondence. Two scientific concepts of understanding the right to the confidentiality of correspondence are characterized. The so-called "personal" concept, which considers this right as a component of the right to privacy and family life, and the second concept justifies the independence of this right, the content and purpose of which is broader than the protection of privacy. The perception of the right to confidentiality of correspondence in the context of the right to private and family life is common. It is substantiated that the "personal" concept is characterized by the connection between the right to confidentiality of correspondence and the right to private and family life, as well as the consideration of the right to confidentiality of correspondence as a separate element of the right to privacy. Instead, the second concept considers the right to confidentiality of correspondence as an independent right that has a relative connection with the sphere of private life and is a separate personal human right. It is noted that the Constitutional of Ukraine derives the right to confidentiality of correspondence in a separate article from the inviolability of private and family life, which leads to the conclusion that it is inexpediency to narrow the right to confidentiality of listening, telephone conversation, telegraph and other correspondence only in privacy or family life.

An analysis of the latest normative changes in the legal regulation of ensuring the right to confidentiality of correspondence in Ukraine of separate categories of persons, in particular on the restriction of the right to convicted and higher guarantees of the right to confidentiality of correspondence of deputies of Ukraine, are committed.

Key words: the "personal" concept of the right to the confidentiality of correspondence; the right to the confidentiality of listening, telephone conversation, telegraph and other correspondence; the right to privacy life; the right to family life; persons sentenced to imprisonment; people's deputies; lawyers.

DOI: $10.36695 / 2219-5521.4 .2020 .19$

УДК 340.91

\section{M.А. ПАНФЬОРОВА}

Марина Анатоліївна Панфьорова, кандидат історичних наук, доцент, доцент Національного транспортного університету*

ORCID: 0000-0002-7901-862X

\section{ПРАВА ЛЮДИНИ В УКРАЇНІ: ІСТОРИКО-ТЕОРЕТИЧНИЙ ВИМІР}

Постановка проблеми. Однією з нагальних проблем сучасного світу і України зокрема $є$ проблема прав людини, створення системи їх надійного захисту, затвердження дієвих гарантій реалізації. Гостроти історико-правовим дослідженням даної теми для України додає поєднання національного, іноземного та радянського досвідів у її розвитку, постійна увага до обраної проблеми в українському суспільстві.

Аналіз останніх досліджень і публікацій. Тема є достатньо дослідженою в межах окремих періодів або документів, але комплексних робіт, що дають оцінку проблеми з історико-правової точки зору, не вистачає. Важливі питання досліджуваної проблеми розглядалися в таких працях вітчизняних учених, як М.М. Антонович, Ю.М. Бисага, М.М. Палінчак, Д.М. Бєлов, М.М. Данканич, О.М. Мироненко, М.І. Луцький, В.В. Кожан та інших.

(C) М.А. Панфьорова, 2020

* Maryna Panforova, Ph.D. in History, Associate Professor, Associate Professor of the National Transport University 
У збірках документів, роботах науковців, у підручниках та хрестоматіях наявні опубліковані документи тієї доби. Це дає змогу аналізувати окремі проблемні аспекти державно-правової історії України, зокрема й проблему прав людини.

Формулювання мети статті. Аналіз етапів та особливостей розвитку прав людини на території України у міждисциплінарному вимірі теорії та історії держави і права.

Виклад основного матеріалу. Згідно з аналізом М. Антонович в українській юридичній науці під правами розуміють «можливості вибору особою певної поведінки для забезпечення свого нормального існування і розвитку, закріплені в законах, інших правових актах держави і міжнародних документах, обумовлені рівнем економічного, соціального, духовного і культурного розвитку суспільства». Попередниками слова

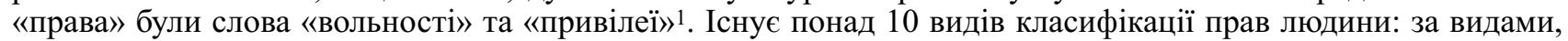
групами прав, колом осіб, обсягом, поколіннями тощо. У найбільш загальному трактуванні основними правами людини є універсально визнані цінності, закріплені міжнародними конвенціями та конституціями держав ${ }^{2}$.

Історично визнання прав людини державою і відповідне законодавче оформлення залежало від рівня розвитку суспільства і таких компонентів форми держави, як форма правління та форма політичного устрою. Окремі права людини в правових джерелах України науковці знаходять ще в документах X-XI ст. ст. (міжнародні угоди з Візантією та «Руська правда»). Зокрема, йдеться про право людини, звинуваченої у злочині, на розгляд ії̈ справи судом, про відсутність смертної кари, повагу до власності, досить високий статус жінки тощо 3 . На той час наявність навіть таких прав випереджала наявні аналоги.

Дослідники пов' язують початок формування громадянського суспільства з буржуазно-демократичними революціями в Західній Європі XVII-XVIII ст. ст., коли ліквідуються станові та корпоративні обмеження, з'являється формальна, але рівність перед законом, виникають перші конституційні документи4.

Україна саме в XVI-XVII ст. ст. активно боролася за свої права. Результати цієї боротьби закріплювалися в міжнародних угодах, гетьманських універсалах, знаходили прояви в козацькому звичаєвому праві. До цього періоду належать перші документи конституційного характеру. Саме в цей час на територію України поширювалася дія Литовських Статутів, які містили норми конституційного (державного) права і закріплювали права окремих станів у формі привілеїв.

Так, договірні статті гетьманів з царським урядом науковці відносять до міжнародно-правових угод, що регулювали державне право або до перших конституцій ${ }^{5}$. За другу половину XVII ст. було підписано вісім таких документів: Березневі статті 1654 р., Переяславські 1659 р., Батуринські 1663 р., Московські 1665 р., Глухівські 1669 р., Конотопські 1672 р., Переяславські 1674 р. та Коломацькі статті 1687 р. Крім того, у XVIII ст. було підписано односторонні Решетилівські статті 1709 р. та «Рішительні пункти» 1728 p.

Спільною рисою цих документів був пункт про підтвердження «давніх прав, даних від великих князів литовських і королів польських». У всіх українсько-московських договорах підкреслювалося, що українські козаки і шляхта залишаться при своїх вольностях, правах і привілеях, гарантувалися окремі станові права духовенству і міщанам. На практиці це означало, що в Україні продовжать діяти гетьманська адміністрація і козацькі суди, які у своїй роботі керуватимуться «малоросійськими правами», під якими розумілися норми Литовського Статуту, магдебурзького права та актів гетьманської влади. Ці норми, на думку сучасників, достатньо забезпечували економічні інтереси української козацько-шляхетської верхівки, її станові права та автономістські прагнення 6 .

На думку Т.О. Матвєєвої, відсилка до малоросійських прав проводилася без чіткого їх тлумачення і фактично зовсім не означала повного повернення старих порядків. Особливо на Півдні України, де більшість правових традицій в чистому чи дещо зміненому виді була привнесена в процесі заселення цієі території вихідцями з інших регіонів країни․

3 іншого боку, дослідники, і зокрема В.З. Прус, аналізують окремі статті і вважають, що ідея державності персоніфікувалася в привілеях різних станів населення держави. Так, ст. 1 Березневих статей 1654 p. формулювала непорушність прав і вольностей козацького стану в управлінні, суді та в приватноправових відносинах; ст. 6 гарантувала права духовного стану й голови духовенства, київського митрополита. Відмічають, що усі статті проєкту договору, що мали забезпечувати непорушність суспільного устрою і привілеї усього населення держави без різниці станів, у затверджених статтях було значно обмежено, зокрема, щодо прав і вольностей міського населення та селянства. Залишалися в силі традиційне судочинство, в яке царським воєводам не дозволялося втручатися, лише частково про це йшлося в ст. 1 про непорушність прав і вольностей козацького стану в суді, під цим фактично розумілося збереження традиційної системи судів, зокрема копних, сотенних, полкових та Генерального судув.

Наприклад, якщо звернутися до тексту Глухівських статей 1669 р., в них на початку бачимо загальне підтвердження попередніх положень статей Б. Хмельницького, але далі йдуть статті, обумовлені тогочасною практикою. Зокрема, ст. 8 про захист від свавілля царських послів та гінців, ст. 15 про захист козаків від царських воєвод, ст. 25 про захист козацької власності, вдів та спадкоємців, ряд статей про права міщан і звільнення певних міст від податків на визначений термін 9 .

На тій частині України, яка перебувала під впливом Польщі або Туреччини, теж прагнули до збереження зазначених раніше «давніх прав». Так, у Гадяцькому трактаті 1658 р. Івана Виговського з Польщею закріплювалася свобода козаків «у радах, судах і вільних виборах панів своїх», спеціально підкреслювалася цілковита рівність православних і католиків ${ }^{10}$. 
Вершиною конституційної думки козацького періоду або нового часу вважається Конституція Пилипа Орлика 1710 року. Вона включала статті про «захист недоторканності законів і вольностей; про право власності не тільки Гетьмана, а и ченців, священиків, бездітних удів, виборних і рядових козаків, двірських слуг і приватних осіб; про право обирати козацьких і простих урядників, а особливо полковників вільним волевиявленням і голосуванням; про право вдів козаків, їхніх дружин та дітей-сиріт, жінок, чоловіки яких перебувають на війні або на якихось військових службах, бути вільними від загальних повинностей та сплати податків» ${ }^{11}$.

Незважаючи на те, що Конституція не стала чинною, вона свідчить про вектор розвитку українського суспільства та права, за які воно боролося.

Протягом другої половини XVII-XVIII ст. відбувався процес обмеження і ліквідації української автономії на українських землях, зміни соціальної структури в напрямку повернення станів, зменшення національних особливостей. Тож, про права людини на державному рівні і в сучасному розумінні не йшлося. Але навіть за таких умов вони продовжували існувати, підтверджуючи загальну тенденцію відповідності прав людини вольностям і привілеям окремих груп і станів ${ }^{12}$.

В XIX ст. виникає поділ права на галузі. Конституційне право тривалий час для українських земель не було чітко оформленим через характер держав, до складу яких вони входили та особливості їхнього розвитку у складі імперій. Хоча в конституційних законах Австро-Угорщини містився достатньо широкий перелік прав людини ще у XIX ст. Це і загальні природні права, політичні, економічні, соціальні, національні. На думку науковців, це надавало державно-правовій системі Австро-Угорщини більшої демократичності, ніж у Російській імперії того ж періоду. Інше питання, що багато з них залишалися формальними ${ }^{13}$.

Наступним етапом національного розвитку України є доба визвольних змагань (1917-1922рp.). За ці 5 років було видано багато документів конституційного характеру, існували різні погляди на подальший розвиток нашої держави, послідовно розвивалися і закріплювалися права людини.

До конституційних документів цього періоду, в яких можна знайти положення про права людини, відносяться універсали Центральної Ради, Конституція УНР 1918 р., Закони про тимчасовий державний устрій України 29 квітня 1918 р., проєкт основних законів Української держави 1918 р., проєкт Конституції Української держави 1918 р. тощо.

Вже I Універсал Центральної Ради проголошував права людей на участь в політичному житті країни: обирати та бути обраними, гарантії вільного вибору, рівність перед законом.

Більш детально прав людини торкався III Універсал. Зокрема, визнавалося право на трудову власність та іiї законодавче регулювання, право на працю та її гідні умови, скасовувалася смертна кара, наголошувалося на необхідності справедливого і професійного суду, поваги до честі та гідності людини ${ }^{14}$. Крім того, проголошувалося забезпечення таких свобод, як: свобода слова, друку, віри, зібрань, союзів, страйків, недоторканості особи й помешкання, право й можливість уживання місцевих мов у зносинах з усіма установами. Універсал торкався і прав інших національностей, що мешкали в Україні. «Український народ... буде твердо охороняти волю національного розвитку всіх народностей, на Україні сущих, тому оповіщаємо: що народам великоруському, єврейському, польському й іншим на Україні признаємо національно-персональну автономію для забезпечення їм права та свободи самоврядування в справах їх національного життя» ${ }^{15}$.

Вищезазначені права підтверджувалися IV Універсалом і знайшли логічне продовження в Конституції УНР від 29 квітня 1918 р. (Статут про державний устрій, права і вольності УНР). В Загальних положеннях «забезпечення права і охорони вільностей, культури і добробуту своїх громадян» проголошувалося метою новоствореної УНР, народ визнавався носієм суверенітету та джерелом влади ${ }^{16}$.

II розділ був повністю присвячений правам громадян України і містив 14 статей. Крім норм, які визначали статус громадянства, в розділі були наявні норми щодо природних, особистих, політичних, соціальних, економічних прав людини незалежно від громадянства. Серед прав були закріплені вже задекларовані в універсалах, проголошувалася рівність людей незалежно від статі, походження, віри, національності, освіти, майнового стану. Містилися гарантії від свавілля судових та правоохоронних органів: «...не може бути затриманий на території іiі без судового наказу інакше, як на гарячім вчинку. Але і в такім разі він має бути випущений не пізніше, як за 24 години, коли суд не встановить якогось способу його затримання»17.

Потребує уваги той факт, що відповідно до теорії природних прав людини, права на життя, свободу і власність розглядалися як тісно пов'язані між собою. Зокрема, конфіскація майна прирівнювалася до приниження людської гідності як і тілесні покарання. Закріплювалися свобода пересування, недоторканість житла та таємниця листування. Порушення цих норм встановлювалося лише у встановлених законом випадках ${ }^{18}$.

На відміну від Центральної Ради, за часи Української держави П. Скоропадського конституційний лад змінився, оскільки за «Законами про тимчасовий устрій України» державна влада зосереджувалась в руках однієї особи. Незважаючи на централізацію влади, тенденція до збереження і гарантування прав людини зберігалася. Акцент ставився на те, що переважна віра в Україні православна, але свобода віросповідання не порушувалася. До того ж, Закон закріплював права на судовий захист, особисту свободу, недоторканність оселі, вільне місце проживання і виїзд за кордон ${ }^{19}$.

Доволі помітним було тлумачення політичних прав, оскільки попередні документи через республікансько-демократичну тенденцію за часів Центральної Ради їх докладно не торкалися. «Українські козаки і громадяни мають право робити зібрання в метах, не шкідливих законом, мирно і без зброї. Кожний може в межах, установлених законом, висловлюватися і писати свої думки, а рівно розповсюджувати їх шляхом 
друку або іншими засобами. Українські козаки і громадяни мають право гуртувати громади і спілки в метах, не противних законам» 20 .

Вищезазначені права людини були закріплені і в проєкті основних законів Української держави 1918 р., новими були тільки окремі статті про сімейне право: «Для лиць нежелающихъ заключать исповедныхь браковъ, или ими довольствоваться, устанавливаются законные браки гражданскіе, съ правомъ развода въ случаяхь, установленныхъ закономъ» ${ }^{21}$. Якщо вести мову про Проєкт Конституції Української Держави, він фактично дублював Закони в скороченому варіанті, але потрібно наголосити на його демократичній тенденції, в загальних рисах він був схожий на Конституцію УНР.

Уряд Директорії частково вже мав конституційний досвід під час Центральної Ради, але вектор їх соціальної політики дещо змінився - він почав більше орієнтуватись на трудові класи і в Декларації Української Директорії від 26 грудня 1918 р. було зазначено, що влада належить не всьому народові, а суто трудовим класам. До того ж, «експлуататорським класам» було заборонено виставляти своїх кандидатів до Трудового Конгресу22.

Систематизуючим документом, який узагальнив законодавство під час становлення Директорії УНР став «Основний державний закон УНР». Він детально закріпив способи, за якими набувався стан громадянства, рівність усіх громадян перед законом та судом, рівність чоловіка та жінки, недоторканність майна та житла, право на освіту, право на вільний вибір праці, право на політичні права, держава забезпечувала охорону законом інтелектуальної власності, здоров’я та життя людини. Окремо можна зазначити, що чужинці не мали політичних прав, а в іншому вони підлягали законам так само як і громадяни ${ }^{23}$.

У ЗУНР, на думку дослідників, законодавство, не зважаючи на несприятливі обставини, мало соціальний характер. Особливий вплив на законодавство ЗУНР мала Тимчасова Конституція, прийнята 13 листопада 1918 р. («Тимчасовий Основний Закон про державну самостійність українських земель бувшої австроугорської монархії»). У ній закріплювалось верховенство і суверенітет народу в державі, загальне, рівне, пряме виборче право, таємне голосування, пропорційна система. Виборчим правом наділялися всі громадяни, без урахування національності і статі 24 . Законом 1919 р. «Про вживання мови у внутрішнім та зовнішнім урядуванні державних властей і урядів, публічних інституцій й державних підприємств на Західній області УНР» державною мовою проголошувалася українська, а іншим гарантувалася державна підтримка та захист. За національними меншинами закріплювалося право вживати рідні мови в урядових відносинах 3 державною владою та урядом, а державним органам відповідати рідною мовою тих громадян, які звертаються до них, їм гарантувалося право вільно користуватися рідною мовою, мати школи, бібліотеки, видавати періодику, книги 25 . В проєкті Конституції 1920 р. Станіслава Дністрянського наголошувалося, що держава визнає людину, з її правами та свободами, важливою соціальною цінністю. Окрема увага приділялася самовизначенню народів ${ }^{26}$.

Щодо радянського періоду розвитку, то права людини у всіх радянських Конституціях хоча і розвивалися теоретично: як за обсягом, так і термінологічно, але були здебільшого декларативними.

У першій радянській Конституції 1919 р. було лише чотири розділи, в одному з яких закріплювалася диктатура трудящих та експлуатованих мас пролетаріату і найбіднішого селянства. У другій Конституції 1929 р. $з$ п’яти розділів, третій був присвячений тільки виборчим правам, позбавляючи таких прав, крім членів царської родини, душевнохворих та чиновників силових відомств, зокрема й осіб, що використовували найману працю, жили з нетрудового прибутку, а саме: відсотків з капіталу, прибутку з підприємств, надходжень 3 майна і т. ін.; приватних крамарів, торговельних і комерційних посередників; духівництво, служників релігійних культів, якщо це заняття було їхньою професією, та ченців 27. У період НЕПу, незважаючи на загальну тенденцію повернення до приватного господарства, права людини не знайшли свого закріплення на конституційному рівні.

Конституції УРСР 1937 та 1978 рр. включали окремі розділи з основних прав та обов’язків громадян. Попри широкий перелік, передусім проголошувались економічні та культурні права. «Серед політичних декларувалось право об’ єднуватись у політичні партії, що за умов монопартійного режиму сприймалось як фікція. Не проголошувалось у цих Конституціях і право на зміну місця проживання, право на страйк тощо» 28. Дослідники відмічають численні розбіжності між конституційною теорією та практикою їі реалізації в умовах тогочасного тоталітарного режиму.

Висновки. Отже, права людини протягом всієї історії перебували в Україні в центрі уваги суспільства і держави. Це зумовлено як власним державно-правовим розвитком, так і зовнішнім впливом. При цьому слід наголосити на зв'язку між розвитком суспільства, формою держави та правами людини. Можна виділити декілька етапів розвитку прав людини в документах конституційного характеру. Це X-XI ст. ст., XVIXVIII ст. ст., 1917-1920 рр. та радянський період. Розвиток прав людини відбувався від окремих прав у давній період, через права груп і станів у формі вольностей та привілеїв у новий час, до розширення даної категорії як за обсягом, так і за колом осіб у наступні періоди. У цілому така тенденція пов'язана 3 національновизвольною боротьбою, перебуванням у складі різних держав, процесом обмеження і ліквідації української автономії, розвитком власного державотворення. У центрі уваги передусім перебували економічні права i право на захист від свавілля влади.

Проаналізовані конституційні документи різних державних утворень, які існували в Україні в 1917-1920 pр., дають підстави стверджувати, що незалежно від їх політичної спрямованості в них послідовно розвивалися, закріплювалися та гарантувалися основні природні, соціальні, економічні та політичні 
права людини. Увесь комплекс прав людини можна умовно поділити на дві групи: ті, що були зумовлені конкретними історичними обставинами (характерні для різних державних утворень) і незалежні від часу, загальнолюдські права, які визнавалися всіма. До цієї групи можна віднести право на життя, свободу, віросповідання, рівність перед законом, рівність незалежно від статі, походження, народності, свободу слова, недоторканність житла та таємницю листування. Незважаючи на несприятливі зовнішні умови, відсутність певний час власного досвіду державно-правового будівництва, політичні сили, що стояли на чолі українського державотворення в цей період не пішли шляхом диктатури та утисків прав людини і громадянина. Це створює певну конституційну традицію щодо ставлення до прав людини як до найбільшої цінності. Стосовно радянського періоду розвитку, то тема прав людини і в цей період не була замовчуваною: перелік прав людини послідовно розширювався у радянських конституціях попри їх декларативність та розходження 3 практикою.

1 Антонович М.М. Еволюція поняття прав людини та проблема їх класифікації. Право Украӥни. 2005. № 12. С. 16.

2 Кожан В.В. Класифікація особистих прав людини. Науковий вісник УЖНУ. 2015. № 35. С. 25 (Серія «Право»).

3 Антонович М. Україна в міжнародній системі захисту прав людини: монографія. Київ : Видавничий дім «КM Асаdеmia», 2000. C. 26.

4 Бисага Ю.М., Палінчак М.М., Бєлов Д.М., Данканич М.М. Права людини. Ужгород : Ліра, 2003. С. 13-14.

5 Там само. С. 128-129; Козаченко А.І. Державно-правове становище України на кінець XVII - початок XVIII ст. Державне будівниитво та місиеве самоврядування. 2006. № 11. С. 126; Прус В.З. Березневі статті Б. Хмельницького 1654 року як джерело права Лівобережної України першої половини XVIII століття. Наше право. 2015. № 2. С. 13.

6 Бисага Ю.М., Палінчак М.М., Бєлов Д.М., Данканич М.М. Права людини. Ужгород : Ліра, 2003. С. 16-17.

7 Матвєєва Т.О. Законодавство Гетьманщини у 18 столітті. Форум права. 2016. № 2. С. 116.

8 Прус В.З. Березневі статті Б. Хмельницького 1654 року як джерело права Лівобережної України першої половини XVIII століття. Наше право. 2015. № 2. С. 15.

9 Дем'ян Многогрішний. Глухівські статті. Ізборник. URL: http://litopys.org.ua/suspil/sus121.htm (дата звернення 10.01.2021)

10 Бисага Ю.М., Палінчак М.М., Бєлов Д.М., Данканич М.М. Права людини. Ужгород : Ліра, 2003. С. 17.

11 Антонович М. Україна в міжнародній системі захисту прав людини: монографія. Київ : Видавничий дім «КМ Асаdemia», 2000. C. 27.

12 Антонович М.М. Еволюція поняття прав людини та проблема їх класифікації. Право України. 2005. № 12. С. 10.

13 Кондратюк О.В. Судова система та судочинство в Галичині в складі Австро-Угорщини (1867-1918): автореф. дис. ... канд. юрид. наук: 12.00.01. Львів, 2006. С. 11.

14 Хрестоматія з історії держави і права України: у 2-х т. / за ред. В.Д. Гончаренка. Київ: Ін Юре, 2000. Т. 2. С. 21-22.

15 Там само. С. 24.

16 Конституційні акти України 1917-1920. Невідомі конституції України. Київ: Філософська і соціологічна думка, 1992. C. 73 .

17 Там само. С. 74

18 Там само. С. 75 .

19 Хрестоматія з історії держави і права України: у 2-х т. / за ред. В.Д. Гончаренка. Київ : Ін Юре, 2000. Т. 2. С. 63.

20 Там само. С. 64.

21 Мироненко О.М. Витоки українського революційного конституціоналізму 1917-1920 рр.: теоретико-методологічний аспект. Київ : Інститут держави і права ім. В.М. Корецького, 2002. С. 225.

22 Конституційні акти України 1917-1920. Невідомі конституції України. Київ : Філософська і соціологічна думка, 1992. C. 73 .

23 Там само. С. $127-131$.

24 Луцький М.І. Правова характеристика конституційного законодавства в ЗУНР. Науковий вісник Ужгородського національного університету. 2014. Випуск 27. Т. 1. С. 31 (Серія «Право»).

25 Там само. С. 32

26 Стецюк П. Станіслав Дністрянський як конституціоналіст. Львів, Жовква : Місіонер, 1999. С. 158-159.

27 Конституція (основний закон) Української Радянської Соціалістичної Республіки 1929 року. URL: http://static.rada.gov. $\mathrm{ua} /$ site/const/istoriya/1929.html (дата звернення 10.01.21)

28 Антонович М. Україна в міжнародній системі захисту прав людини: монографія. Київ : Видавничий дім «КМ Асаdemia», 2000. C. 29.

\section{Резюме}

\section{Панфьорова М.А. Права людини в Україні: історико-теоретичний вимір.}

У статті проаналізовано етапи та особливості розвитку прав людини на території України у міждисциплінарному вимірі теорії та історії держави і права. Зроблено акцент на документах конституційного характеру різних періодів та правах людини, закріплених у них. Проблему розглянуто в давній, козацький, 1917-1921 рр. та радянський періоди, від окремих прав, через вольності та привілеї станів, до розширення поняття за обсягом і колом осіб. Обгрунтовано висновок про безперервність української державно-правової традиції і такі фактори впливу на розвиток прав людини, як національно-визвольна боротьба, входження до складу різних держав, процеси обмеження і ліквідації української автономії, розвиток власного державотворення.

Ключові слова: права людини, етапи розвитку, вольності, привілеї, стани, державно-правові традиції, конституційні документи, соціально-економічні права. 


\section{Резюме}

Панфёрова М.А. Права человека в Украине: историко-теоретический аспект.

В статье проанализированы этапы и особенности развития прав человека на территории Украины в междисциплинарном измерении теории и истории государства и права. Сделан акцент на документах конституционного характера и правах человека, закрепленных в них. Проблема рассмотрена в древний, казацкий, 1917-1921 гг. и советский периоды, от отдельных прав, через вольности и привилегии сословий, к расширению понятия прав человека по объему и кругу лиц. Обоснован вывод о непрерывности украинской государственно-правовой традиции и такие факторы влияния на развитие прав человека, как национально-освободительная борьба, пребывание в составе разных государств, процессы ограничения и ликвидации украинской автономии, развитие собственной государственности.

Ключевые слова: права человека, этапы развития, вольности, привилегии, сословия, государственно-правовые традиции, конституционные документы, социально-экономические права.

\section{Summary}

Maryna Panforova. Human rights in Ukraine: historical and theoretical dimension.

The article presents the result of a historical and theoretical study of human rights in Ukraine. Emphasis is placed on the constitutional documents of different periods and human rights enshrined in them. The problem was considered in the Ancient, Cossack, 1917-1921 and Soviet periods, from individual rights, through the freedoms and privileges of the estates, to the expansion of the concept in terms of volume and range of persons. The conclusion about the continuity of the Ukrainian state and legal tradition and such factors influencing the development of human rights as the national liberation struggle, joining various states, the processes of limiting and eliminating Ukrainian autonomy, the development of their own statehood is substantiated.

The analyzed constitutional documents of various state formations that existed in Ukraine in 1917-1920 give grounds to assert that regardless of their political orientation, they consistently developed, consolidated and guaranteed basic natural, social, economic and political human rights. The whole complex of human rights can be divided into two groups: those that were due to specific historical circumstances (characteristic of different state entities) and independent of time, universal human rights, which were recognized by all. This group includes the right to life, liberty, religion, equality before the law, equality regardless of gender, origin, nationality, freedom of speech, inviolability of home and secrecy of correspondence. Despite unfavorable external conditions, the lack of some experience of state and legal construction, the political forces that led the Ukrainian state formation in this period did not follow the path of dictatorship and oppression of human and civil rights. This creates a certain constitutional tradition of treating human rights as the greatest value. As for the Soviet period of development, the topic of human rights was not silenced at all during this period either: the list of human rights was consistently expanded in the Soviet Constitutions, despite their declarativeness and differences with practice.

Key words: human rights, stages of development, freedoms, privileges, estates, state and legal traditions, constitutional documents, socio-economic rights.

DOI: $10.36695 / 2219-5521.4 .2020 .20$

УДК 342.565 .2

\section{О.Г. ТУРЧЕНКО}

Ольга Григорівна Турченко, кандидат юридичних наук, доцент, завідувач кафредри Донецького національного університету імені Василя Стуса*

ORCID: 0000-0001-7446-1289

\section{КОНСТИТУЦІЙНА СКАРГА В КОНТЕКСТІ ПРИНЦИПУ ВЕРХОВЕНСТВА ПРАВА}

Постановка проблеми. Захист прав та свобод людини та громадянина $є$ однією з основних завдань кожної сучасної демократичної і правової держави. Так, в основу Конституції України покладено концепцію дотримання прав та свобод людини, визнання їх невід'ємними та непорушними, відповідно, «права і свободи людини та їх гарантії визначають зміст і спрямованість діяльності держави» (ст. 3) ${ }^{1}$. Разом із тим ефективне дотримання прав та свобод неможливе без забезпечення принципу верховенства права.

Стаття 8 Конституції України регламентує «визнання і дію» принципу верховенства права. Треба погодитися з позицією М. Козюбри, що верховенство права передбачає інтерпретацію його через складові, які, передусім, охоплює ст. 3 Конституції України, що закріплює обов'язок держави щодо поваги до прав людини. Відповідно як безпосередній прояв реалізації верховенства права необхідно розглядати спрямованість діяльності органів влади та їхніх посадових осіб на забезпечення фундаментальних, невідчужуваних прав людини ${ }^{2}$.

На думку Т.Р.С. Аллана, саме однакова гідність усіх громадян і справедливе ставлення й повага до індивідуальної автономії є серцевиною принципу верховенства права ${ }^{3}$.

Загальне визначення терміна «верховенство права» було викладено в рішенні Конституційного Суду України від 2 листопада 2004 р. № 15-рп/2004: «Верховенство права - це панування права в суспільстві. Вер-

(C) О.Г. Турченко, 2020

* Olha Turchenko, Ph.D. in Law, Associate Professor, Head of the Department of Vasyl`Stus Donetsk National University 